〔J. Appl. Glycosci., Vol. 48, No. 2, p. 99-103 (2001)]

\title{
A Lectin from the Shoots of Bamboo Phyllostachys pubescens
}

\author{
Hirokazu Kawagishi, ${ }^{*}$ Kanae Henmi, Yoshihisa Oiwake, Takeomi Murata and Taichi Usui \\ Department of Applied Biological Chemistry, Faculty of Agriculture, Shizuoka University \\ (836, Ohya, Shizuoka 422-8529, Japan)
}

\begin{abstract}
A lectin was isolated from the shoots of bamboo Phyllostachys pubescens by using affinity chromatography on Sephadex G-75. In hemagglutination inhibition assays, this lectin exhibited a binding specificity toward maltose and methyl $\alpha$-mannoside. The $N$-terminal sequence was determined as Lys-Ser-Cys-Cys-Pro-Ser-Thr-Thr-Ala and identical with that of the American mistletoe toxin, ligatoxin A.
\end{abstract}

Traditionally people eat bamboo shoots in Japan and the other Asian countries. However hardly any chemical or biochemical studies on the constituents of the material have been done. In the course of our screening for new lectins from various organisms, ${ }^{1-3)}$ we found lectin activity in the sap of the shoots of bamboo Phyllostachys pubescens. Here we describe the isolation and characterization of the lectin.

\section{MATERIALS AND METHODS}

Materials. Bamboo shoots Phyllostachys pubescens Mazel were collected at Shizuoka City, Japan, frozen upon collection, and stored at $-30^{\circ} \mathrm{C}$. Sephadex G-75 and Superose 12 HR10/30 column were products of Pharmacia (Sweden). Spectra/Por 1 was a product of Spectrum Medical Industries (USA). All sugars for the hemagglutinating inhibition tests were products of Nacalai Tesque (Japan), Wako Pure Chemical (Japan) or Sigma (USA). All glycoproteins for the test were purchased from Sigma (USA). BIAcore 2000 was a product of Biacore AB (Sweden).

\footnotetext{
${ }^{*}$ Corresponding author.

Abbreviations: PPL, Phyllostachys pubescens lectin; PBS, $10 \mathrm{~mm}$ phosphate-buffered saline ( $\mathrm{pH}$ 7.4); HBS, 10 mM HEPES buffered saline (pH 7.4); BSM, bovine submaxillary mucin; PAGE, polyacrylamide gel electrophoresis; ME, 2-mercaptoethanol. All sugars are of D-configuration unless otherwise stated.
}

Purification of PPL. All the procedures were carried out at $4^{\circ} \mathrm{C}$ except for defrosting. After defrosting, the bamboo shoots were homogenized in a blender and centrifuged $(10,000 \times g, 30 \mathrm{~min})$. To the supernatant, 4 volumes of 5-fold concentrated PBS and ME were added, giving a crude lectin solution in PBS containing $1 \mathrm{mM}$ ME. The lectin solution was applied to a Sephadex G-75 column $(1.8 \times 35 \mathrm{~cm})$ equilibrated with the same buffer. The lectin activity weakly bound to the column and was eluted at the bed volume of the column. The lectin-containing fraction was concentrated by ultrafiltration (UK-500, Advantec, Japan) and applied to the Sephadex G-75 column equilibrated with the buffer again. The lectin fraction was dialyzed using Spectra/Por 1 against distilled water and lyophilized, giving a purified lectin (PPL).

Hemagglutination test. Human blood was collected in $3 \%$ sodium citrate. The erythrocytes were washed three times with PBS and suspended at a concentration of $3 \%$ in the buffer.

A $10 \%$ suspension of erythrocytes in PBS (10.0 $\mathrm{mL})$ was treated with Pronase $\mathrm{P}(7.0 \mathrm{mg})$ for 30 $\min$ at $47^{\circ} \mathrm{C}$, and then the erythrocytes were washed three times with the buffer and suspended at a concentration of $3 \%$ in the buffer.

A $10 \%$ suspension of erythrocytes in PBS (10.0 $\mathrm{mL}$ ) containing $0.05 \% \mathrm{BSA}$ was treated with Clostridium perfringes sialidase (Worthington Biochemical Corporation, USA, $140 \mathrm{mU} / \mathrm{mL}$ ) for $4 \mathrm{~h}$ 
at $37^{\circ} \mathrm{C}$, then the erythrocytes were washed three times with the buffer and suspended at a concentration of $3 \%$ in PBS.

Agglutination of $3 \%$ erythrocytes and inhibition of the agglutination by sugars and glycoproteins were done in 96-well microtiter U-plates. The titer was defined as reciprocal of the end-point dilution causing hemagglutination. Inhibition was expressed as the minimum concentration of each sugar required for inhibition of hemagglutination of titer 4 of the lectin.

SDS-PAGE. SDS-PAGE was carried out by the method of Laemmli. ${ }^{4}$ Samples were heated in the presence or absence of $\mathrm{ME}$ for $10 \mathrm{~min}$ at $100^{\circ} \mathrm{C}$. Gels were stained with Coomassie Brilliant Blue.

Gel filtration for molecular weight estimation. Gel filtration for measuring the molecular weight of native lectin was carried out on a Superose 12 HR10/30 column with a FPLC system. The molecular weight standards (Pharmacia, Sweden) used were ferritin ( $\mathrm{Mr} 440,000)$, catalase $(232,000)$, bovine serum albumin $(67,000)$, ovalbumin $(43,000)$, chymotrypsinogen A $(25,000)$, and ribonuclease A $(13,700)$.

Sugar analysis. Sugar content was measured by the phenol-sulfuric acid method with reference to glucose.

Amino acid analysis. The lectin was hydrolyzed with $6 \mathrm{M} \mathrm{HCl}$ at $110^{\circ} \mathrm{C}$ for $24 \mathrm{~h}$ in a sealed evacuated tube and analyzed on a Hitachi L-8500 A amino acid analyzer.

$N$-terminal amino acid analysis. The $N$-terminal amino acid of the protein was analyzed on a PPSQ-10 Protein Peptide Sequencer (Shimadzu, Japan).

Thermostability. Samples in PBS were heated for $30 \mathrm{~min}$ at the temperatures indicated, cooled on ice, and titrated.

pH Stability. The $\mathrm{pH}$ dependence of the lectin was measured by incubating the samples in the following buffers for $24 \mathrm{~h}$ at room temperature: $0.02 \mathrm{M}$ sodium acetate buffer $(\mathrm{pH} 3.5-5.5), 0.02 \mathrm{M}$ sodium phosphate buffer ( $\mathrm{pH} 6.0-7.5$ ), $0.02 \mathrm{M}$ Tris$\mathrm{HCl}$ buffer ( $\mathrm{pH} 8.0-9.0$ ), and $0.02 \mathrm{M}$ glycine$\mathrm{NaOH}$ buffer (ph9.5-10.5).

Surface plasmon resonance analysis. Real time detection of PPL binding to glycoproteins was recorded by using a BIAcore 2000. PPL was immobilized covalently via its primary amines to carboxyl groups within a dexran layer on the sensor chip CM-5 according to the manufacturer's specifications. During the immobilization, maltose (1 $\mathrm{mM}$ ) was added to the coupling buffer in order to protect the sugar-binding site in the lectin. Glycoproteins at various concentrations in HBS were injected over immobilized PPL at $20 \mathrm{~mL} / \mathrm{min}$. After injection of each protein, HBS was introduced onto the sensor surface to start the dissociation. The data were analyzed by BIAevaluation 3.0 software (Biacore AB, Sweden). ${ }^{12}$

\section{RESULTS AND DISCUSSION}

The purification procedure is summarized in Table 1. Since the lectin activity was unstable, the purification procedure was done successively without lyophilization. Therefore the protein amounts in the first two steps are not given in Table 1. Fresh shoots of bamboo $P$. pubescens were homogenized in a blender and centrifuged. To the obtained supernatant, 5-fold concentrated PBS and ME were added. Without ME, the lectin was deactivated gradually. Since this crude lectin solution showed a binding specificity toward Glc and Man,

Table 1. Purification of PPL (from $117 \mathrm{~g}$ of fresh bamboo shoots).

\begin{tabular}{|c|c|c|c|c|}
\hline Step & $\begin{array}{l}\text { Total protein } \\
\quad(\mathrm{mg})\end{array}$ & $\begin{array}{l}\text { Total agglutination } \\
\text { activity (titer) }\end{array}$ & $\begin{array}{l}\text { Specific agglutination } \\
\text { activity (titer } / \mathrm{mg} \text { ) }\end{array}$ & $\begin{array}{l}\text { Recovery of } \\
\text { activity }(\%)\end{array}$ \\
\hline 1. Supernatant after homogenization & - & 3840 & - & 100 \\
\hline $\begin{array}{l}\text { 2. Eluate from first affinity chromatog- } \\
\text { raphy }\end{array}$ & - & 3328 & - & 88.7 \\
\hline $\begin{array}{l}\text { 3. Eluate from second affinity chroma- } \\
\text { tography }\end{array}$ & 1.1 & 3072 & 2800 & 80.0 \\
\hline
\end{tabular}

${ }^{a}$ Measured with type A Pronase-treated blood cells. 
Sephadex G-75 was chosen as the affinity support. The lectin activity weakly bound to the affinity column and eluted at the bed volume of the column. The obtained lectin-containing fraction was applied to the affinity column again. Pure lectin, PPL, was obtained by the two affinity chromatography processes.

The molecular weight of PPL estimated by gel filtration was 48,000 (data not shown). Figure 1 shows SDS-PAGE of the protein. Unreduced lectin appeared as a broad single band of molecular weight of about 13,000 . The reduced one showed a diffused band of molecular weight of less than 13,000 . These results show that this lectin is composed of several subunits. Although size homogeneity was suggested by gel filtration and SDSPAGE in the absence of ME, isoelectric focusing over the $\mathrm{pH} 3.50-9.50$ indicated a family of bands focusing in the $\mathrm{pH}$ zone between 4.5 and 5.3 (data not shown). Sugar content of the lectin was $8.8 \%$. Amino acid analysis revealed a high content of Asx, Gly, and Ala, and a low content of Tyr, Met, Pro, and His (Table 2). Amino acid sequence analysis gave no evidence of heterogeneity in the primary structure of the first $9 \mathrm{~N}$-terminal residues

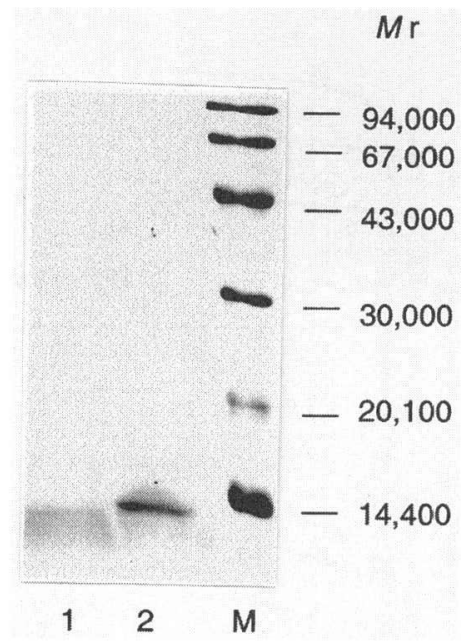

Fig. 1. SDS-PAGE of PPL.

Lane 1, PPL (reduced with 2-mercaptoethanol); lane 2, PPL (non-reduced); lane M, marker. The molecular weight standards (Pharmacia, Sweden) used were phosphorylase b (Mr 94,000), albumin (67,000), ovalbumin (43,000), carbonic anhydrase $(30,000)$, trypsin inhibitor $(20,100)$, and $\alpha$-lactalbumin $(14,400)$.
Table 2. Amino acid composition of PPL.

\begin{tabular}{cr}
\hline Amino acid & mol\% \\
\hline Asx & 15.9 \\
Thr & 7.4 \\
Ser & 4.8 \\
Glx & 9.6 \\
Gly & 15.4 \\
Ala & 13.7 \\
Val & 4.2 \\
Met & 0.9 \\
Trp & n.d. ${ }^{a}$ \\
Ile & 4.4 \\
Leu & 5.3 \\
Tyr & 0.8 \\
Phe & 2.7 \\
Lys & 8.1 \\
His & 1.4 \\
Arg & 4.1 \\
Pro & 1.3 \\
Cys & n.d. \\
\hline
\end{tabular}

${ }^{a}$ n.d., not determined.

(Lys-Ser-Cys-Cys-Pro-Ser-Thr-Thr-Ala). The reason for the diffusion of the band in SDS-PAGE in the presence of ME is not clear but the subunits might have some intramolecular S-S linkage $(\mathrm{s})^{2)}$ or might be due to heterogeneity of the sugar chains among the subunits of the protein. Interestingly, the $N$-terminal sequence of the lectin was identical with that of ligatoxin A which is a toxin isolated from the American mistletoe Phoradendron liga. ${ }^{56}$ Taxonomically the bamboo and the mistletoe belong to different subclasses. The $\mathrm{LD}_{50}$ of the toxin, determined by intraperitoneal injection in mice, is $1.00 \pm 0.08 \mathrm{mg} / \mathrm{kg}$ bodyweight. ${ }^{\text {) }}$ In Japan and China, people never eat raw bamboo shoots and usually eat them after heat treatment such as boiling because the raw shoots are toxic. The lectin activity was stable under $40^{\circ} \mathrm{C}$; however temperatures higher than $45^{\circ} \mathrm{C}$ caused rapid deactivation of the lectin activity after incubation for $30 \mathrm{~min}$. The molecular weight of ligatoxin A is about 5000 and composed of a single chain of 46 amino acids. It would be interesting to know whether the whole primary structure of the lectin still has homology to ligatoxin A and the raw shoots' toxicity is due to the lectin or not. The lectin was stable for a $\mathrm{pH}$ range from 4.0 to 10.5 after incubation at room temperature for $24 \mathrm{~h}$. 
PPL exhibited a slight preference for type B erythrocytes. Sialidase and Pronase treatments increased the sensitivity of erythrocytes to agglutination by the lectin (Table 3 ).

In the hemagglutination inhibition assay, ${ }^{1,2)}$ maltose was the strongest inhibitor among the monoand oligo-saccharides used (Table 4). Methyl $\alpha$ mannoside, mannose and methyl $\alpha$-glucoside were also inhibitory. However, methyl $\beta$-glucoside did not inhibit PPL-mediated hemagglutination even at concentrations up to $400 \mathrm{~mm}$. These results indicate that this lectin is an $\alpha$-glucosyl specific lectin. All the glycoproteins used were completely inert even at $1 \mathrm{mg} / \mathrm{mL}$ in the assay. However, surface plasmon resonance analysis using BIAcore

Table 3. Agglutination profiles of PPL $(100 \mu \mathrm{g} / \mathrm{mL})$.

\begin{tabular}{cccc}
\hline & \multicolumn{3}{c}{ Titer $^{\circ}$} \\
\cline { 2 - 4 } Group of & Unthroated & $\begin{array}{c}\text { Pronase } \\
\text { treated }\end{array}$ & $\begin{array}{c}\text { Sialidase } \\
\text { treated }\end{array}$ \\
\cline { 2 - 4 } & 16 & 256 & 128 \\
Human A & 32 & 512 & 256 \\
Human B & 16 & 256 & 128 \\
Human O & 16 & \\
\hline
\end{tabular}

${ }^{a}$ Defined as reciprocal of the end dilution causing hemagglutination.
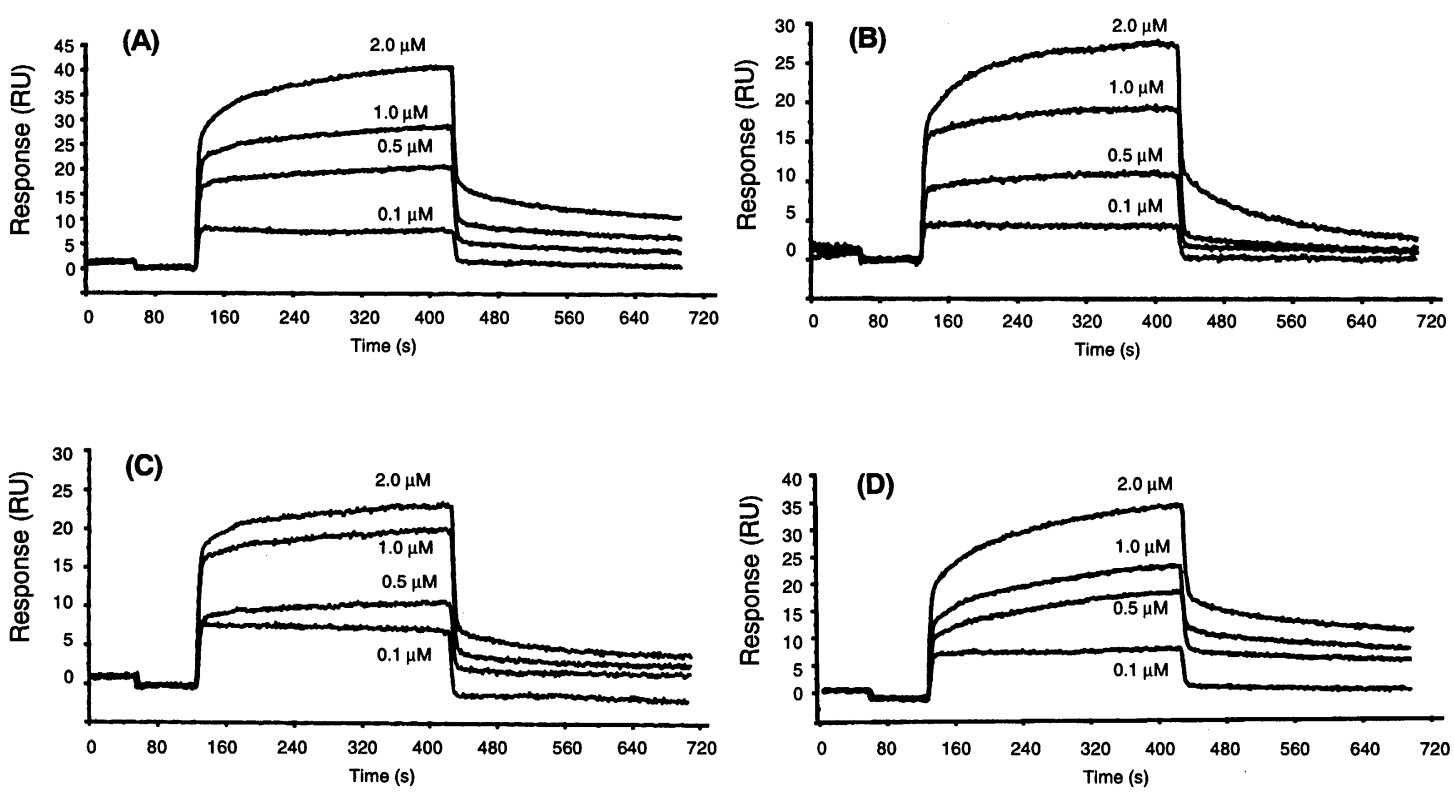

Fig. 2. Sensorgrams showing the interaction between immobilized PPL and glycoproteins.

(A), asialo-BSM; (B), BSM; (C), asialo-fetuin; (D), fetuin.

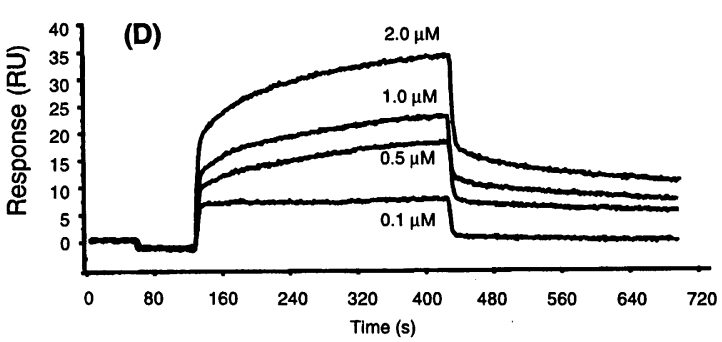

2000 gave kinetic data for the binding between immobilized PPL and 4 glycoproteins (Fig. 2 and

Table 4. Inhibition of the hemagglutination activity of PPL by mono-, oligo-, polysaccharides and glycoproteins.

\begin{tabular}{lcc}
\hline \multicolumn{1}{c}{ Inhibitors $^{a}$} & $\begin{array}{c}\text { Minimum } \\
\text { inhibitor } \\
\text { concentration } \\
\left(\mathrm{mM}^{b}\right)^{b}\end{array}$ & $\begin{array}{c}\text { Specific } \\
\text { factor }^{c}\end{array}$ \\
\hline Maltose & 12.5 & 1.0 \\
Methyl $\alpha$-mannoside & 25 & 2.0 \\
Mannose & 50 & 4.0 \\
Methyl $\alpha$-glucoside & 50 & 4.0 \\
Methyl $\beta$-mannoside & 100 & 8.0 \\
Glucose & 100 & 8.0 \\
Fructose & 100 & 8.0 \\
Lactose & 200 & 16.0 \\
Sorbose & 200 & 16.0 \\
\hline
\end{tabular}

${ }^{a}$ Galactose, methyl $\beta$-glucoside, GalNAc, GlcNAc, ManNAc, LacNAc, L-arabinose, mannitol, L-rhamnose, xylose, D- and L-fucose, sorbitol, glucuronic acid, $N$ acetylneuraminic acid, and GlcNAc $\beta 1 \rightarrow 4$ Man did not inhibit at all at concentrations up to $400 \mathrm{mM}$. BSM, asialoBSM, fetuin, asialo-fetuin, transferrin, and $\alpha_{1}$-acid glycoprotein did not inhibit at all at concentrations up to 1 $\mathrm{mg} / \mathrm{mL} .{ }^{b}$ Minimum concentration required for inhibition of 4 hemagglutination dose of the lectin. ${ }^{c}$ Calculated in relation to maltose. 
Table 5. Kinetic analysis of the interaction of immobilized PBL and glycoproteins by using BIAcore.

\begin{tabular}{lccc}
\hline \multicolumn{1}{c}{ Analyte } & $\begin{array}{c}k_{\text {on }} \\
\left(\mathrm{M}^{-1} \mathrm{~s}^{-1}\right)\end{array}$ & $\begin{array}{c}k_{\text {off }} \\
\left(\mathrm{s}^{-1}\right)\end{array}$ & $\begin{array}{c}K_{\mathrm{A}} \\
\left(\mathrm{M}^{-1}\right)\end{array}$ \\
\hline Asialo-BSM & $3.40 \times 10^{3}$ & $1.92 \times 10^{-3}$ & $1.78 \times 10^{6}$ \\
BSM & $1.93 \times 10^{3}$ & $4.97 \times 10^{-3}$ & $3.89 \times 10^{5}$ \\
Asialo-fetuin & $3.40 \times 10^{3}$ & $1.79 \times 10^{-3}$ & $1.90 \times 10^{6}$ \\
Fetuin & $4.37 \times 10^{3}$ & $1.22 \times 10^{-3}$ & $3.59 \times 10^{6}$ \\
\hline
\end{tabular}

Table 5). Usually in the case of binding analysis of lectins to sugars or glycoproteins by using BIAcore, sugars or glycoproteins are immobilized as ligands and lectins are used as analytes, because lectins are deactivated in the immobilizing conditions. ${ }^{6-12)}$ However, after various attempts, we succeeded in immobilization of PPL without deactivation in the presence of a specific binding sugar, maltose. The bindings of the lectin to all the glycoproteins were very weak; the association rates $\left(k_{\text {on }}\right)$ were very slow and the dissociation rates $\left(k_{\text {off }}\right)$ were very rapid compared with previously reported kinetic data on the binding between other lectins and glycoproteins or sugars. ${ }^{7-12)}$ There is no significant difference among those kinetic data for the glycoproteins.

PPL is produced by the shoots of bamboo $P$. pubescens. However, lectin activity was not detected in the extract of the mature bamboo (data not shown). So far as we are aware, this is the first lectin isolated from the genus Phyllostachys.

\section{REFERENCES}

1 ) H. Kawagishi: Mushroom lectins. Food Rev. Int., 11, 63-68 (1995).

2 ) H. Kawagishi, M. Yamawaki, S. Isobe, T. Usui, A. Kimura and S. Chiba: Two lectins from the marine sponge Halichondria okadai; An $N$-acetyl-sugar specific lectin (HOL-I) and an $N$-acetyllactosamine specific lectin (HOL-II). J. Biol. Chem., 269, 1375-1379 (1994).

3 ) H. Kawagishi, H. Mori, A. Uno, A. Kimura and S. Chiba: A sialic acid-binding lectin from the mushroom Hericium erinaceum. FEBS Lett., 340, 56-58 (1994).

4 ) U.K. Laemmli: Cleavage of structural proteins during the assembly of the head of bacteriophage T4. Nature, 227, 680-685 (1970).

5 ) J.T.J. Lecomte, D. Kaplan, M. Llinás, E. Thunberg and G. Samuelsson: Proton magnetic resonance char- acterization of phoratoxins and homologous proteins related to cramblin. Biochemistry, 26, 1187-1194 (1987).

6) E. Thunberg and G. Samuelsson: Isolation and properties of ligatoxin A, a toxic protein from the mistletoe Phoradendron liga. Acta Pharm. Suec., 19, 285-292 (1982).

7 ) P. Alder, S.J. Woods, Y.C. Lee, R.T. Lee, J.W.A. Petri and R.L. Schnaar: High affinity binding of the Entamoeba histolytica lectin to polyvalent $N$-acetylgalactosaminides. J. Biol. Chem., 270, 5164-5171 (1995).

8 ) U. Holmskov, P.B. Fisher, A. Rothmann and P. $\mathrm{H} \phi$ jrup: Affinity and kinetic analysis of the bovine plasma C-type lectin collectin-43 (CL-43) interacting with mannan. FEBS Lett., 393, 314-316 (1996).

9 ) A.D. Hutchinson: Characterization of glycoprotein oligosaccharides using surface plasmon resonance. Anal. Biochem., 220, 303-307 (1994).

10) I. Okazaki, Y. Hasegawa, Y. Shinohara, T. Kamasaki and R. Bhikhabhai: Determination of the interactions between lectins and glycoproteins by surface plasmon resonance. J. Mol. Recognition, 8, 95-99 (1995).

11) Y. Shinohara, H. Sota, F. Kim, M. Shimizu, M. Gotoh, M. Tosu and Y. Hasegawa: Use of bossiness based on surface plasmon resonance and bitonal gladdens for analysis of sugar binding specificities of lectins. J. Biochem., 117, 1076-1082 (1995).

12) X. Zeng, T. Murata, H. Kawagishi, T. Usui and K. Kobayashi: Analysis of specific interactions of synthetic glycopolypeptides carrying $N$-acetyllactosamine and related compounds with lectins. Carbohydr. Res., 312, 209-217 (1998).

(Received September 4, 2000; Accepted October 19, 2000)

$$
\begin{gathered}
\text { タケノコ由来のレクチンについて } \\
\text { 河岸洋和, 逸見香苗, 追分誉久 } \\
\text { 村田健臣, 碓水泰市 } \\
\text { 静岡大学農学部応用生物化学科 } \\
\text { (422-8529 静岡市大谷 } 836)
\end{gathered}
$$

未熟モウソウチク（タケノコ）からレクチンを Sephadex G-75を用いたアフィニティークロマトグラ フィーによって単離, 精製した。このレクチンはゲル 濾過によって分子量 48,000 と推定され, 数個の同一 サブユニットから成っていた．赤血球凝集阻害反応に よって, マルトースや $\alpha$-メチルマンノシドに結合特 異性を示すことが判明した． N末端配列は Lys-SerCys-Cys-Pro-Ser-Thr-Thr-Ala であり，これはヤドリギ から得られている ligatoxin A と同一であった. 